\title{
Innovation accelerator to make Portuguese parishes smarter
}

\author{
Inês Vizela ${ }^{1}$, Emanuel Costa ${ }^{2}$, Vítor Santos ${ }^{1}$ \\ 1. NOVA IMS Lisbon Portugal \\ 2.Área Metropolitana de Lisboa Lisbon Portugal
}

This is the Author Peer Reviewed version of the following chapter published by Springer:

Vizela, I., Costa, E., \& Santos, V. (2020). Innovation accelerator to make portuguese parishes smarter. In M. Banat, \& S. Paiva (Eds.), Smart Technologies for Smart Cities: EAl/Springer Innovations in Communication and Computing (pp. 3-21). (EAl/Springer Innovations in Communication and Computing). Springer. https://doi.org/10.1007/978-3-030-39986-3_1

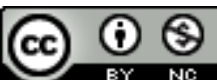

This work is licensed under a Creative Commons Attribution-NonCommercial 4.0 International License. 


\title{
Innovation accelerator to make Portuguese parishes smarter
}

\author{
Inês Vizela ${ }^{1}$, Emanuel Costa ${ }^{2}$, and Vítor Santos ${ }^{3}$ \\ 1 NOVA IMS ines.vizela@outlook.com \\ 2 Área Metropolitana de Lisboa emanuelcosta@hotmail.com \\ 3 NOVA IMS vsantos@novaims.unl.pt
}

\begin{abstract}
The main motivation behind this study was the need to get citizens and parish councils closer. For this purpose, an innovation accelerator to bring smartness to parishes was built. To get all insight, there was the need to learn more about public administration, smart cities and a bit more on innovation and creativity. During the research process was also understood that smartness inside a parish must include an improvement on the relationship with citizens, citizens who feel that their opinions count, citizens training to promote digital inclusion and also for parish employees to make sure that their processes are more citizen-centered, and an improvement of citizens quality of living inside the parish. Those issues were addressed in the final model. The obtained model was validated by a focus group and it was concluded that the implementation of the proposed framework in a Portuguese parish is aligned with what parishes want for them in the near future.
\end{abstract}

Keywords: smart cities - local e-government - innovation accelerator · smart parish · citizens · local public administration · lean startup · agile.

\section{Introduction}

During the last decades of the twentieth century, new concepts for public services arose, associated with them also arose concepts like trust, collaboration, participation and liability as founding stones in administration and citizens' relationships so, there was the compulsory need to grant more power to public administration and to get the citizens more involved in all processes around them [1]. The World Wild Web concept was defined as becoming an essential and revolutionary part of citizens daily lives in different contexts and places. A kind of paradigm shift had occurred which lead to changes not only in the dissemination but also in processing information [1]. Crowd-sourcing is also an interesting topic to be evaluated in the context of this study as a way to use citizens and stakeholders' knowledge to solve municipal problems like the ones they experience during their daily routines. All of this, through e-participation. there was the need for some expertise on this topic inside parishes in order to gather as innovative and creative contributions as possible [2]. A smart place had been considered the one that combines perfectly the physical and the virtual world in 
only one location, where information and communication technologies are considerably essential in order to make the bridge between these two realities [3]. All this new integration of technologies in citizens lives derived into two new research areas related to e-governance, such as how technology mediates citizens participation or e-participation [4]. But, most of the studies were much more focused on the website of this municipalities and not in the overall internal processes and interaction with the citizens. Although this question has been addressed in main cities/municipalities but neglected at a local level. Unfortunately, and despite the implementation of dozens of smart city projects, citizens are still far away from their parish councils [5] and many times, they are made aware of what is being implemented at their own city through the media and not because of a good communication with their parishes. Desires to the near future were also defined on how it should be and how citizens' proximity shall be valued, regarding that, Portuguese republic said in 2018 that public administration power should be decentralized from central to local administration [6] which may be understood as a step ahead on taking citizens and local administration closer. This improvement will only be possible after taking advantage of "the relationship between municipalities and the government" because, nowadays it "is very scarce" which distances local and central administration [7] which may have caused a lack of communication which directly affected citizens. So, the main question that will be addressed with this study is "How to make Portuguese parishes smarter?", to achieve the answer, there was need of an understanding on what kind of technologies, innovation techniques and methods could be useful to obtain a smarter parish. The feeling of transparency between the two main actors of this study has been considered as a key element for the success of local e-government projects and also to be able to lead with a smart democracy system [8]. The reasons for conducting this research were the nonexistence of a smart concept for parishes and the fact that most of smart initiatives were implemented in the context of a municipality and not at a parish level. Parishes were also chosen as the focus of this study as they were considered the most important way to link citizens with public administration, even though this link was made, most of the time, through traditional clerk services. So, parishes needed to become part of today's information society in order to take some advantage from it [9]. As an advantage for this study is the fact that the Portuguese smart cities section was considered the biggest one inside national association of Portuguese municipalities [10], what lead us to think that Portugal invests in smartness and to hope that the output artifact of this study may be implemented in parishes in the future. As another motivation to start this study, there is the fact that e-governance in Portugal has been considered an unknown topic and the majority of parishes does not know how they are supposed to apply this kind of twenty first century hot topics to their daily routines [9]. Another motivational factor to go ahead with this study around innovation for Portuguese parishes was knowing that it was already part of "Lisbon agenda" the aim to create "a knowledge-based economy in Europe driven by innovation" [11]. This chapter is organized as follows first exposing all theoretical framework that gave support to this study including 
public administration, smart cities, innovation and creativity, then the methodology followed is explained and how it applies to this study, then a model of an innovation accelerator for smart cities parishes that arose from the realization of this study is explained in detail as well as the discussion process required for the final model validation. Finally, the study's conclusions are presented as well as the future work which could gave rise to.

\section{THEORETICAL FRAMEWORK}

To start introducing the problem behind this study there was the need for a theoretical background on topics like public administration, smart cities as well as innovation and creativity.

\subsection{Public Administration}

At the global level, there was a need to reinforce what were public administration responsibilities and how to turn it more economical. At the same time, operational strategies and processes should be "organized around fluid models based on teams, communities and collaborative alliances structured in networks of knowledge" and horizontal processes were needed to better fit citizens' needs - "horizontal networks of inter institutional work or value chains" [12]. According to what was mentioned above about the following steps for public administration, it was predicted that collaborative and interdepartmental technologies will take center stage at public administration future initiatives [12]. It was not possible talking about public administration improvements without mentioning the emergence and innovation on e-government services, a theme that was understood as "vital process for administrative modernization" and as a way to obtain openness and agility for public administration to meet society's needs [12]. Although transversal projects were needed to approach administration and administered. Only this way will the efficiency and competitiveness necessary for the success of these initiatives be achieved. The use of technologies aims to "increase citizenship, transparency and citizen participation". This, because technologies could be a very important starting point for administrative modernization, but their success depends entirely on the use that citizens and businesses make of it. However, technology is still seen as a critical success point in promoting digital inclusion associated with administrative modernization [12]. It was also very important to take note that an e-government system mostly requires the use of opinion pools to get citizens and companies closer to government [11] feeling that their opinion counts. Besides that, an improvement will only be possible after taking advantage of "the relationship between municipalities and the government" because, nowadays it "is very scarce" which distances local and central administration [7] which may have caused a lack of communication which directly affected citizens. Customer relationship management systems, may also help, were considered as an important starting point for an improvement in the 
relationship between the public administration and its citizens, taking into account that, with this system it was possible to draw up a profile of each one managed by tailoring the services to their specific needs, it is a system "where the citizen comes into the spotlight" [1]. At a Portuguese level, through the time, Portugal has presented many administrative modernization strategies as an "introduction of administrative simplification systems", "improving the quality of services provided to citizens by the administration" and " dialogue with the citizen" [7] those demonstrated citizens' power inside public administration and how improving the relationship between them and public administration could be crucial to reach a modern public administration. Also, the idea behind using e-government at Portuguese public administration was supported by an assumption that a citizen must communicate with it by different channels and public administration must be responsible to manage an internal workflow to get the answer and return to the citizens as soon as possible [1]. A technological innovation in Portuguese public administration was also a new application called Juntar a Junta, lunched at April 2017, and had as main objective bringing closer parishes and their citizens by an active and aware community [13]. Luís Newton, president of the parish council of Estrela, states that only in 2009 a transversal dynamic implementation with the communities and the citizen was possible, where his involvement began to be valued. The involvement of public administration employees during the changing process facilitated its implementation as well as increased the success rate of it, which was only possible by collecting employee's opinions, which sometimes had included a possible solution to known problems but that were never given an opportunity to share it [14]. Although, elderly people felt more and more they were being left behind and that they did not make part of this new modern world they lived in which represent a big challenge when attempting to modernize public administration as more and more parishes have majorly old populations [15]. It was concluded that any innovation inside Portuguese parishes, should always consider that they must end up with a cost reduction for citizens, an improvement in the way they live or an improvement of the way public entities deliver their services [16] as those are defined as what people were expecting to happen after an implementation of a smart initiative. Regarding local administration, their front office parish competencies are the ones that may help improve the relationship between citizens and parish council, let them be closer to each other. Parish competencies classified as Back office were the ones mentioned in line a), f), g), k), m), o), q), s), t), u), v), x), $\mathrm{y}), \mathrm{z}), \mathrm{aa}), \mathrm{bb}), \mathrm{cc}), \mathrm{ee}), \mathrm{ff}), \mathrm{hh}), \mathrm{ii}), \mathrm{kk}$ ), rr), tt) and licensing of activities like lotteries sales, car upholstery and noisy activities of a temporary nature that respect popular festivals, pilgrimages, fairs, camp and dances, referred in 16th article of the Portuguese law, 75/2013 from September 12th [17].

\section{$2.2 \quad$ Smart Cities}

To introduce smart cities, it was interesting to mention that it is known that around $75 \%$ of the world's population lives in urban areas and that this percentage tends to grow at least to $80 \%$ in 2020 . The main objective of governments 
identified in 2015 was to support this continuous growth by making cities more sustainable, always ensuring the quality of life supported by the implementation of smart cities initiatives [18]. It is also important to reinforced that there was funding for smart-city initiatives inside Portugal, it was only necessary that their implementations went according to the specific needs of the citizens as well as having the necessary involvement of parish employees, which was not always the case and therefore lead to the failure of its implementations [14]. In fact, trying to modernize cities around Portugal had as challenge citizens involvement in e-services and from government side an inability to effectively answer to citizens participation [5]. Although it was recognized that "nothing better than technologies to minimize decision-making arbitrariness," technologies such as "multiple and universal interaction channels, business intelligence, automated reporting and alerting, work flows, mobile technologies" are the future [12]. Smart cities could be a combination of three dimensions that should be perfectly aligned to have success in smart cities initiatives. They are people, community and technology [18]. Smart city 3.0 are the one related with citizens co-creation where citizens were involved in initiatives [19]. Regarding technology, is known that citizens identified advantages on having a website available like being easier to use, the cost reduction and the decrease of the level of bureaucracy inside cities [16]. The major reason identified to unused e-governmental services by citizens were the absence of necessity to use them and the preference for a personal contact service [16].

By 2014 Portugal had a collaborative platform called smart cities Portugal, where "companies, clusters, universities, R\&D centers, municipalities and other economic and social players" acted together to improve smart cities experience inside Portugal [20].

Also about technology and how it is used inside Portuguese public administration, an interesting study made by NOVA IMS students has proved that municipalities provided data to an open source repository because they were bound to do it in a regular attendance, and not because they wanted to share data or even understood the benefits of sharing it regarding the increase of transparency, participation, quality of services, efficiency and economic development $[21]$.

\subsection{Innovation and Creativity}

It was considered important to study innovation and creativity topics a bit deeper as, the truth was that "innovators... need to innovate innovation" [22] every day.

As a consequence, changes around the globe affected the way people do and think innovation. Crowdsourced creativity and software communities are two concepts that emerged during the last decades to accelerate innovation [22].

Although is known that for an innovation to succeed, innovators needed to be part of online communities to spread the news with all interested parts, only by doing so an idea may succeed because it would be known and understood by a group of people [23]. McKinsey in 2018 revealed that people needed to 
feel comfortable on sharing their thoughts and also have the possibility to network with others to mature ideas [24]. Searching by mechanisms that helped on stimulating innovation concepts like broadcasting, brainstorming, licensing out, networking and expert teams were found [25]. Regarding the most common ways to fund innovations, we should mention: personal, family and friends funding, government grants, debt or equity funding, business angels, venture capital, crowd funding [26], academic partners, customers or employees' funds if in a corporate context, bankers [27] and so many other ways of get financial help. Venture capitals and business angels were defined as the ones that by having a prototype of what is being innovated are more likely to invest [28]. Coworking spaces also appeared associate with innovation as they allowed "cost-effective office spaces" with access $24 / 7$ and a community of people who had the know-how about a specific theme/area [29], which may provide access to an "environment of like-minded entrepreneurs, ... specialized experts, ... high-value networking, and seminars" [29]. Combining design thinking, lean startup and agile methodologies made it possible to transform an idea into a business solution that better fits the market by delivering the final solution step by step. What decreased risk level associated with failure after launching new ideas to the market. Also, and one of the most important facts of using this combined approach was considered to get people involved in the process, letting them be more fulfilled with their work and proud of the final solution launched [30]. When thinking about carrying forward an innovation accelerator, what people need to consider first is who will be part of the team, because they were mentioned as the essence of an accelerator and that which will make the difference at go, no-go moment [23]. There is need of a team that involves people from different generations, to get different inputs and perceptions, pursuing a way to meet consumer needs [22]. There are five main elements that characterize an innovation accelerator: first of all there should be a definition of ways of funding created at the end of these initiatives, secondly find "company founders" and recruit people with technical background to be part of the team, after that, define the time window for each group, after having the people and a time window for them to meet, it is time to organize an educational program to advise each team on business/ products and, last but not the least, a "networking program" to join all the teams and advisors to exchange opinions about what was done which may include the final demo day where all innovations that were created are presented to collect insights from people who better know the business [31]. Innovation accelerators were known by including "a fixed-term, cohort-based program, including membership and educational components, that culminates in a public pitch event, or demo day" as well as mentoring, resources and industry connections and, most important, industry connections during these programs [32]. Faster innovation programs like a hackathon differed from innovation accelerators mainly in the fact that they usually did not have the time to let people be familiar with the innovation methodology that needed to be followed, neither changing their mindset according to it. At an innovation accelerator all of these took some time but at the end the results were considered much more disruptive and that better 
fit core business objectives [33]. The type of sponsors generally involved in an accelerator were universities and corporations [32].

\section{Methodology}

After some thought about what should be the process to design an innovation accelerator for parishes, to follow a design science research methodology sounds like the best solution to get things done. The choice of this methodology has had into consideration some of its characteristics like the fascination of combining synthesis brought by the design fundamentals and an analytic point of view that came from a scientific background [34]. In this section it will be explained how all the phases of design science research methodology will be used during this study and what will also be the tasks inside each of them. It is possible to count with a help of the following model to explain it: As shown above, this study started

Theory Metrics, Analysis, Knowledge Disciplinary Knowledge

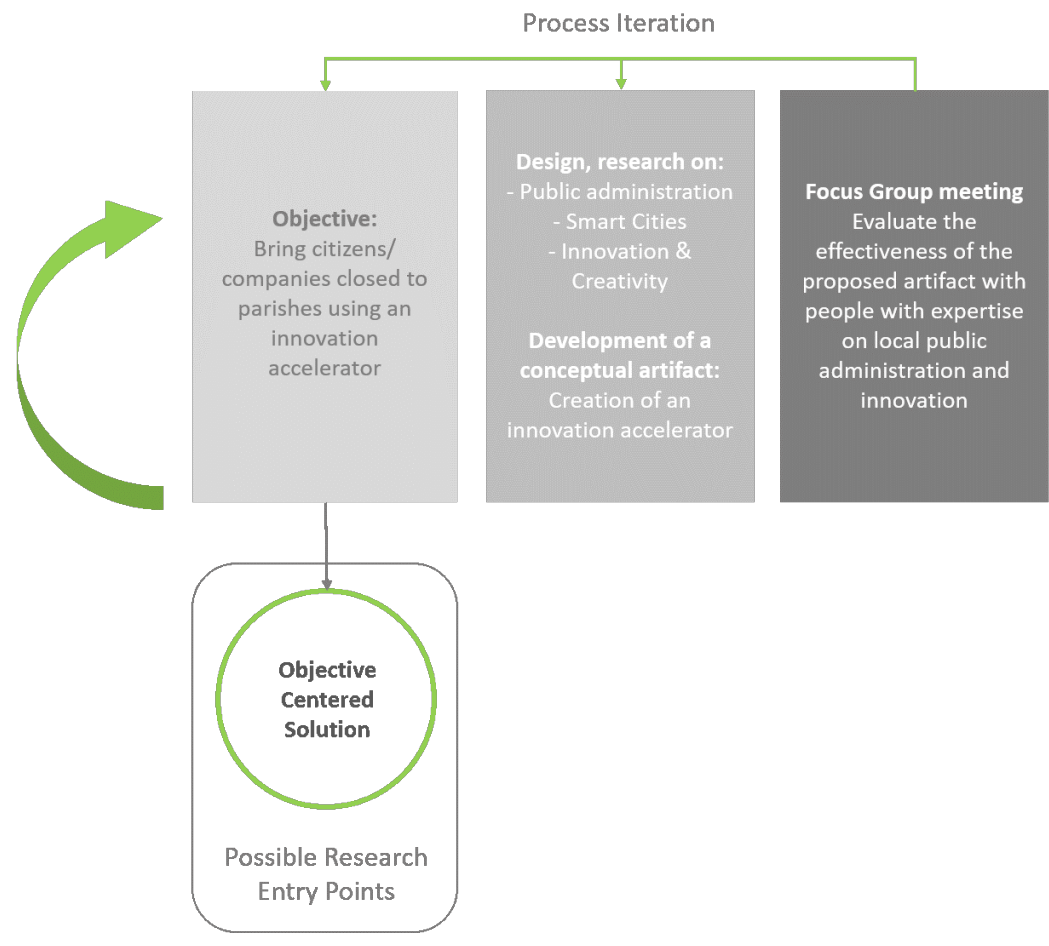

Fig. 1. DSR implementation strategy

at design objectives and solution stages because it was driven by an objective 
centered solution which is to bring citizens/companies closer to parishes using an innovation accelerator. So, to start, there was the need to define objectives and a solution around the main problem identified in the previous paragraph, to get to know which areas the basis of this study should have according to requirements that fitted the solution's goal. Design and development stages involved research around three main themes: public administration, its current technological state and what were the main responsibilities of a parish council in Portugal, smart cities, main concepts and initiatives that were already being done and innovation/creativity and existing methods to boost it. This stage was split into two tasks, the first one explained above and the second one that involved the creation of an innovation accelerator according to what was researched and set as requirement by defining what is essential to get smartness inside parishes. Last stage, inside the scope of this study, but one of the most important ones, evaluation of the output artifact that was done with the help of a focus group meeting to get feedback from participants about what were their impressions about the proposed artifact and how they saw the possibility to implement it based on the context they have on parish council's reality. The moderator was Dr. Emanuel Costa member of executive committee from the Lisbon Metropolitan Area. Participants were three Dr ${ }^{\mathrm{a}}$. Fernanda Marques - director of economical and local development department, Dr. Bruno Martinho - municipal director of economy, innovation and communication and last but not the least José Ricardo Dias Martins - president of Costa de Caparica parish council. Those participants were chosen by the moderator as he better knew people from Lisbon Metropolitan Area Parishes and Municipalities, this chosen were made according to our pre-requirements that were to have at least one people from innovation, one people from a parish and one people from municipality in order to bring knowledge about other parishes as well. Caparica were considered an interesting parish as it already follow a longest path regarding innovation and we wanted to evaluate how aligned the path they followed was with the proposed framework. Also, we wanted to know how the framework fits their next steps on innovation. A person from a municipality was considered mandatory as it has the context not only from urban parishes but also from rural ones.

\section{A model of an innovation accelerator for smart parishes}

After studying Portuguese public administration, smart cities and innovation, it was possible to have a clear notion on what must be included in the definition of the main concept behind this study: a smart parish. In fact, it was understood that a smart parish is the one who wants to improve the relationship between citizens and parishes by promoting the dialogue between them. Including more citizens in the initiatives that happen inside their parish, by listening to their opinions and making them feel like their opinion counts. Also, a smart parish is the one who gives training to parishes council's employees, for them to be more focused on providing a citizen centered service; the focus are the citizens and not only the process and the bureaucracy involved, making citizens closer to parishes. 
Giving IT training to citizens to take advantage of information technologies and promoting digital inclusion is also part of smart parishes' mission. In general, a smart parish must improve the way people live in it by involving who lives and/or works there. At the scope of this study, an innovation accelerator for parishes was proposed, for them to become smart parishes, according to the assumptions described above it was proposed the following conceptual framework. The main goal of the conceptual framework proposed is giving citizens a better quality of life by improving all communication channels between them and parish councils, to get them closer, also by letting them have a voice inside the parish by sharing their concerns, thoughts, giving ideas to improve their daily lives. Who better than the people who work/live inside a parish to have an idea on what is good or bad in it? In figure 2 it is possible to see all the main concepts of the framework and who are the participants of each one. 


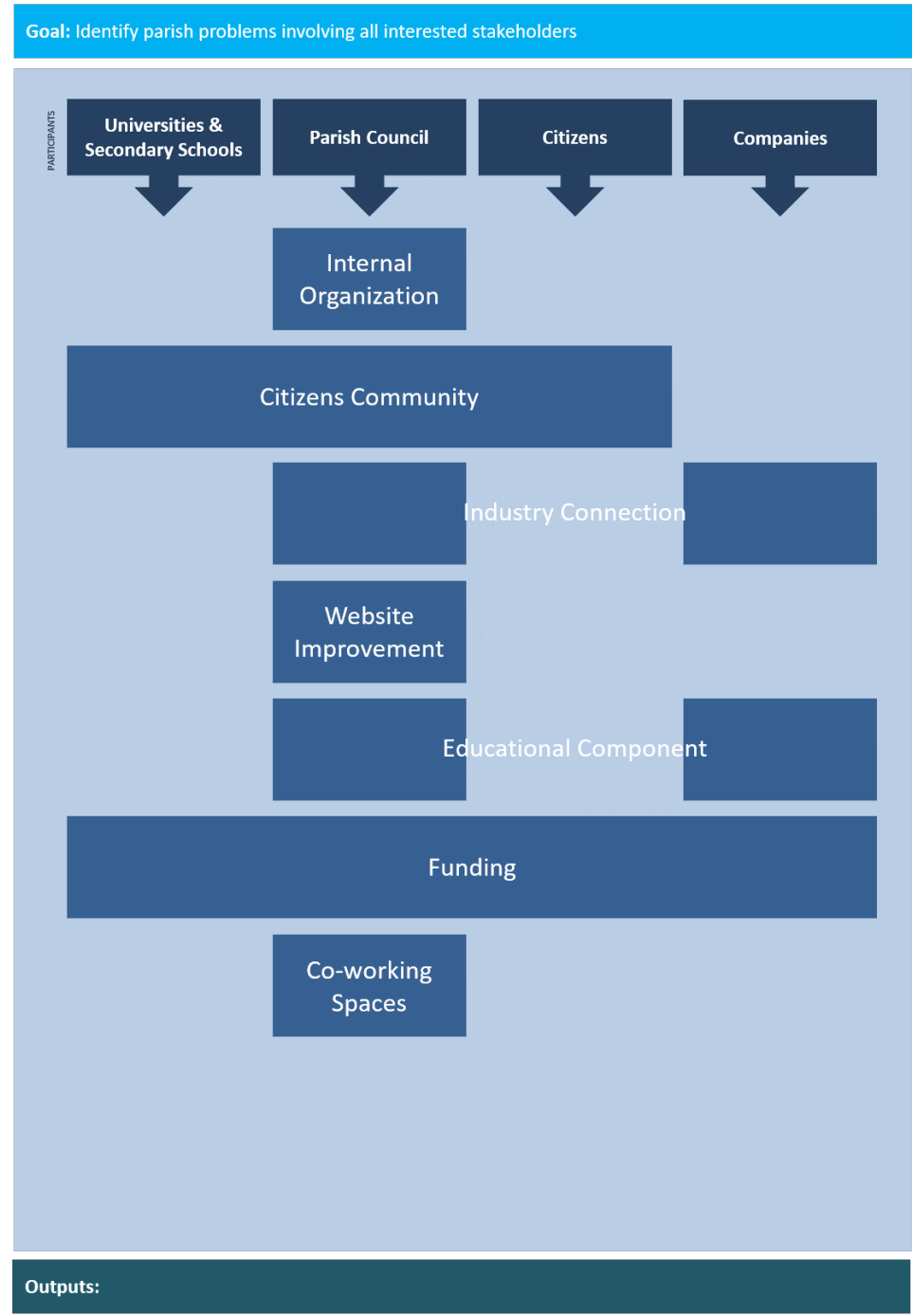

Fig. 2. Framework components

Based on this, it was considered that for a parish to become smarter changes needed to start from inside the parish council. By giving attention to their employees, listening to their ideas, re-organizing processes to be able to respond to citizens in a more effective and efficient way, also involving them in the modernization of services given to citizens by training them on innovation to increase the chances for innovation initiatives to succeed and be accepted inside the parish. Also, citizens needed to feel they belong to a parish which listens to their thoughts and that improves their way of living and this is only possible 
by letting citizens network and brainstorm with each other to create new and disruptive ideas that have real pains behind with a help of mentors from specific areas and from the parish council itself. Industry connections are also needed components in the proposed accelerator as they will catch connections from companies and parish council to find some fund, mentorship and/or physical space to help implementing and guiding innovations. An improvement of parish council's website was considered a mandatory component as, after studied parish councils' competencies, were found that the front-office ones, that directly influence the relationship between citizens and parishes, had a lot to do with providing information to citizens and forms for them to fill in. Also, a website improvement is needed in order to be possible to have a page in which people could submit their ideas and later require funding for them. Because of this, a funding component was also needed at this parish accelerator where citizens (business angels), companies or even the parish council with help from government would help take some innovations to a next level. Considering this wave of innovations, concerns came up, people from parish council needed training to know how to deal with innovation and citizens needed training on how to make use of the e-services they have at their disposal, how to implement their ideas, how to convince people to invest on their ideas taking them to a next level and training to promote digital inclusion. Based on that, education was also considered a mandatory component inside this framework. Co-working spaces had already been implemented inside the context of smart cities and had been a success for people who want a place to work or study without being at home or paying a very high income. Also, as one of the outputs of this framework is to generate ideas, people need a place to do it and to meet with other citizens or even with some investor. So, co-working spaces where a need in the context of the proposed framework. It was considered that the implementation of the proposed framework should start from inside the parish councils to the citizens. So, in general terms, first the parish council will need to rethink and re-organize the way they do things and the services they provide, and only then improve communication channels between citizens and parish council giving voice to citizens and, if possible in the context of the parish, promote an innovation lab where ideas will become reality with help from mentors, funding and training always having in mind the question: how to improve the quality of life of your parish, in the near future? In the next figures innovation accelertor's implementation flow to achieve the goal of making parishes smarter will be presented. It was considered important to set as steps of this implementation an internal organization of the parish council. Where, generally speaking, they will start by considering investing in a new application to be used by their citizens and parish council's employees, then giving voice to internal parish council people listening to their ideas and thoughts as well as to let them participate in website improvement to encourage them to become enablers of innovation. Explaining why it was considered important 
waiting 1 month after communicating the new application existence to citizens, it was due to the fact that it was considered that only after this time will it be possible to evaluate their success not only inside the parish but also as an help for citizens.

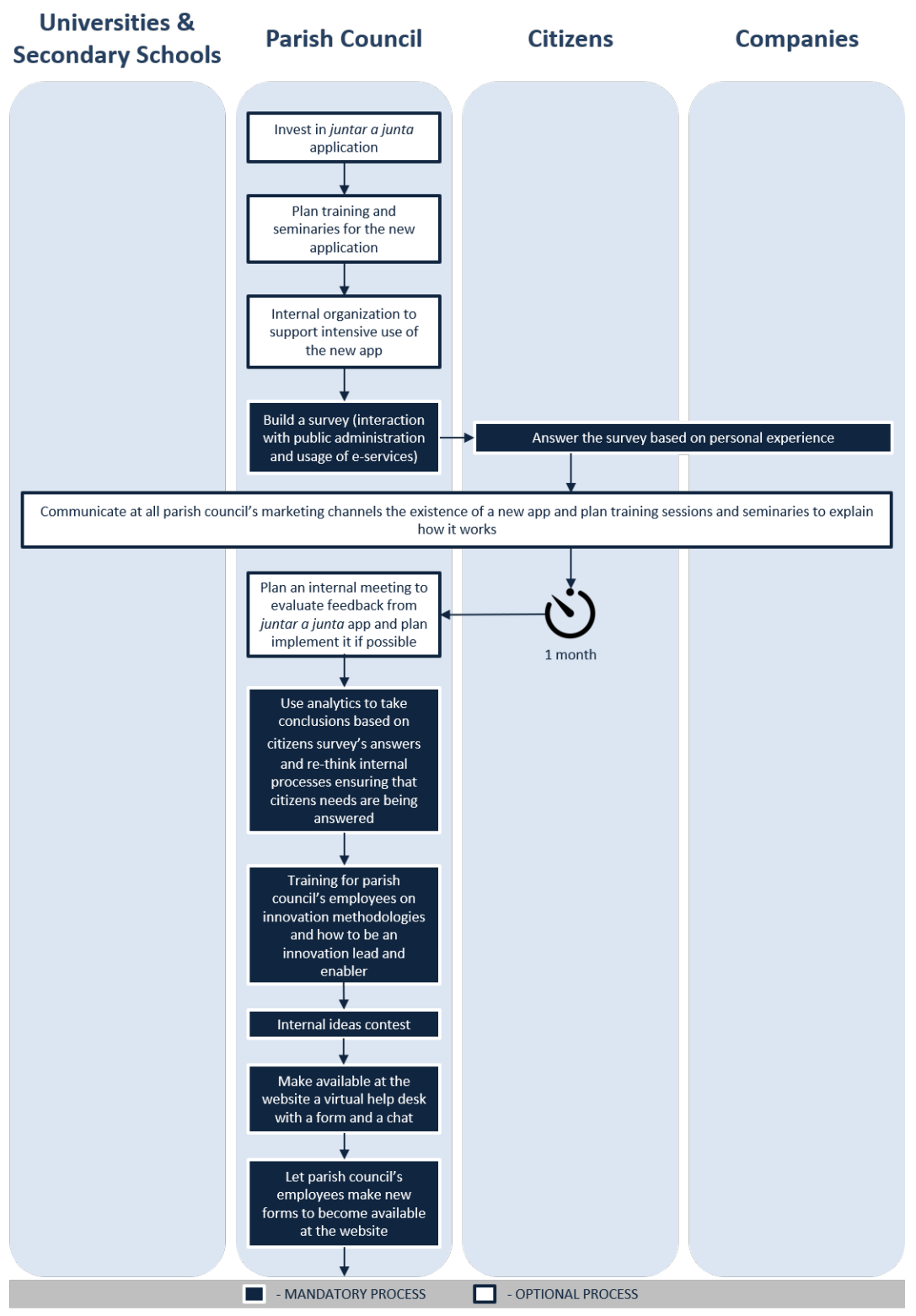

Fig. 3. Framework Implementation Phase 1 
After improving things internally, it was considered that the second phase of implementation of the proposed framework should include an investment and improvement not only in technology but also in the way people use it. So an improvement of parish council's website aligned with their competencies was mandatory as well as an educational component that included citizens and the way they use electronic services made it available by public administration, local and central one.

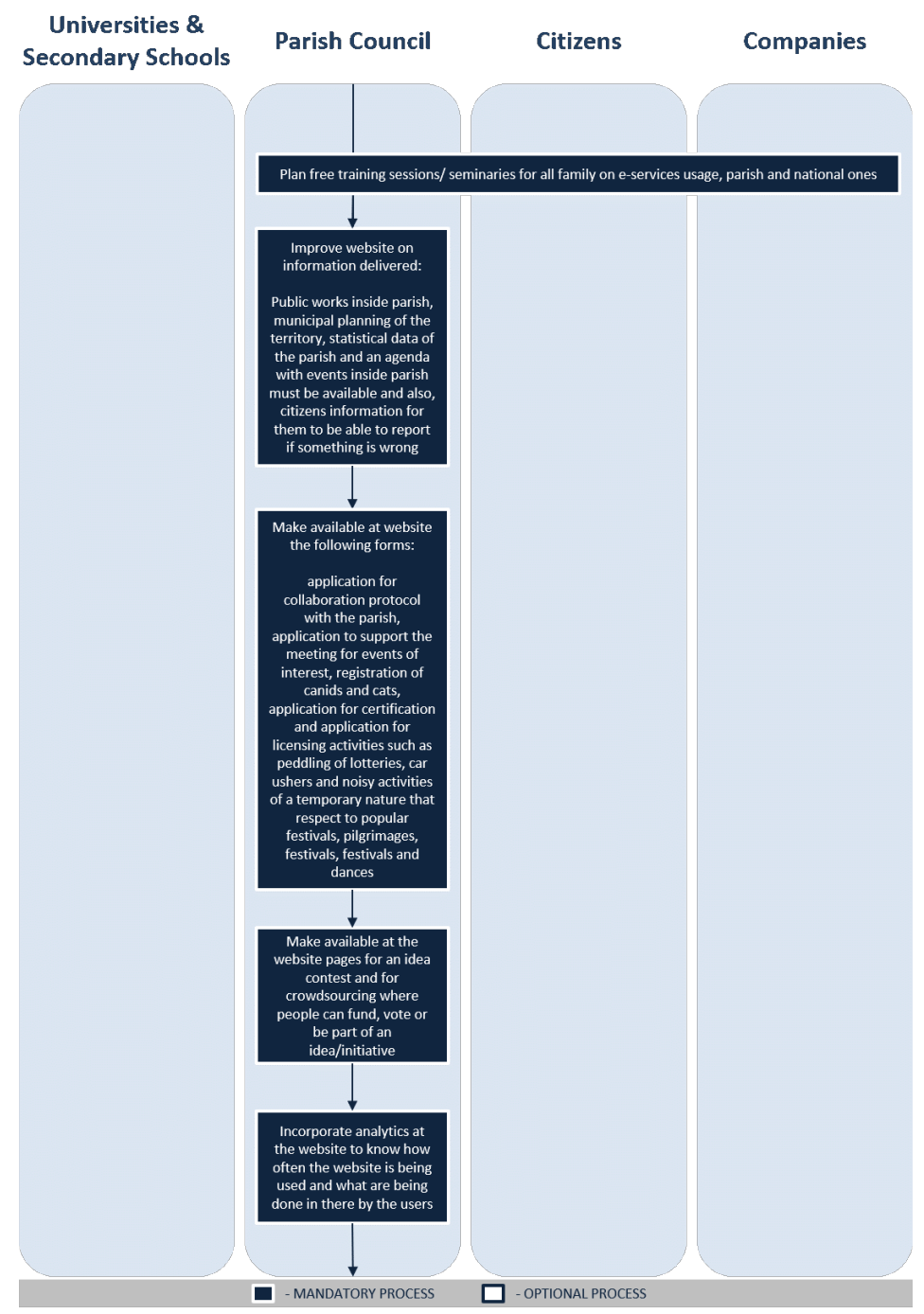

Fig. 4. Framework Implementation Phase 2 
At a third phase of implementation it was considered that it was the stage where parish council was already prepared to involve citizens. It starting by explaining how they should use parish council's website and take advantage from it, as well as investing in a customer relationship management system to improve the knowledge about citizens.

Also at this phase, it was considered important to give citizens a place to study, work, meet or simply join together to exchange some thoughts, as well as letting them have a voice proposing ideas, voting in others ideas or simply by volunteering themselves to join its implementation.

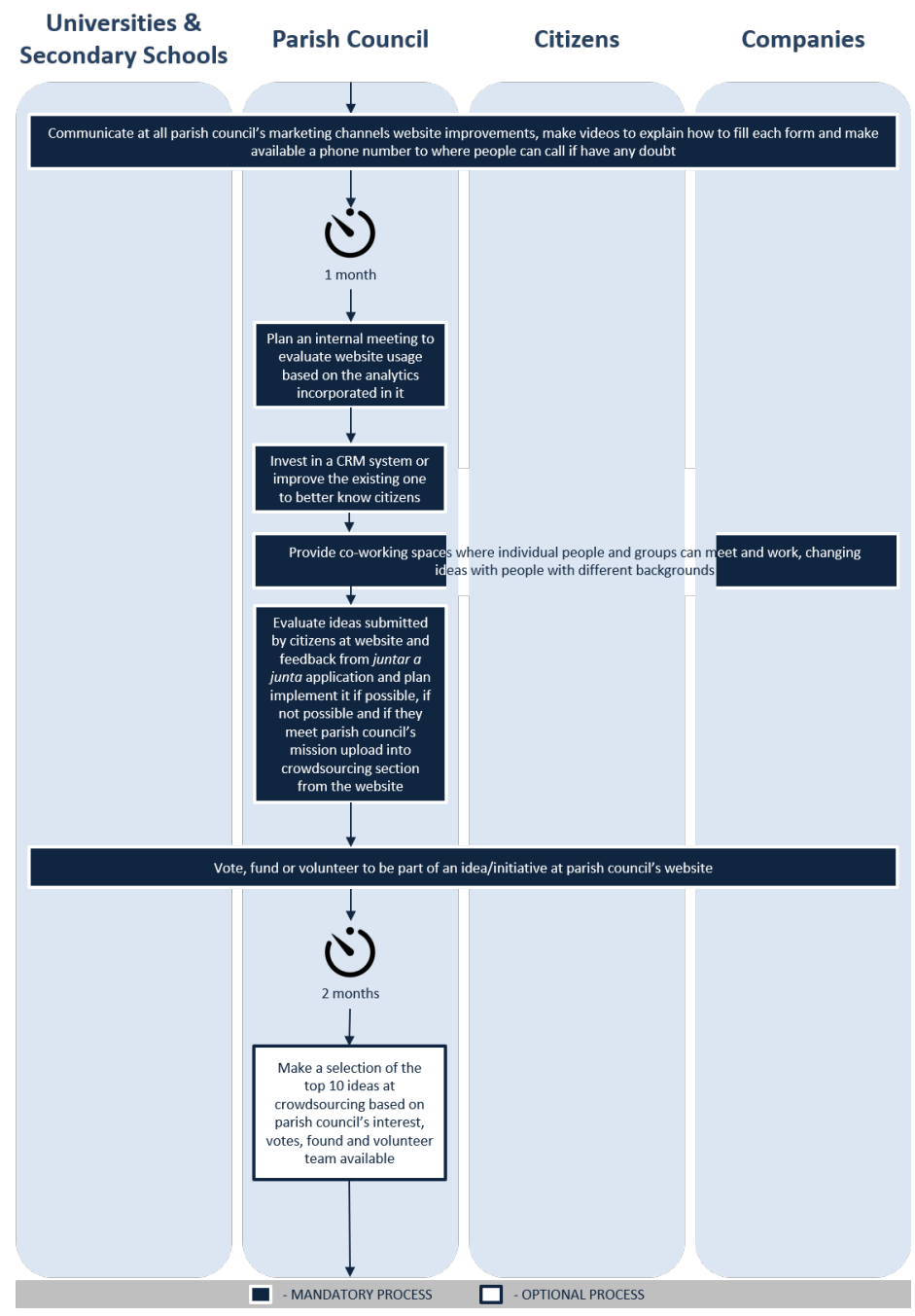

Fig. 5. Framework Implementation Phase 3 
As final and optional phase, there was a need to incorporate something similar to an innovation lab to pick citizens and parish council's employees ideas and make them happen with an help of companies and universities to implement it.

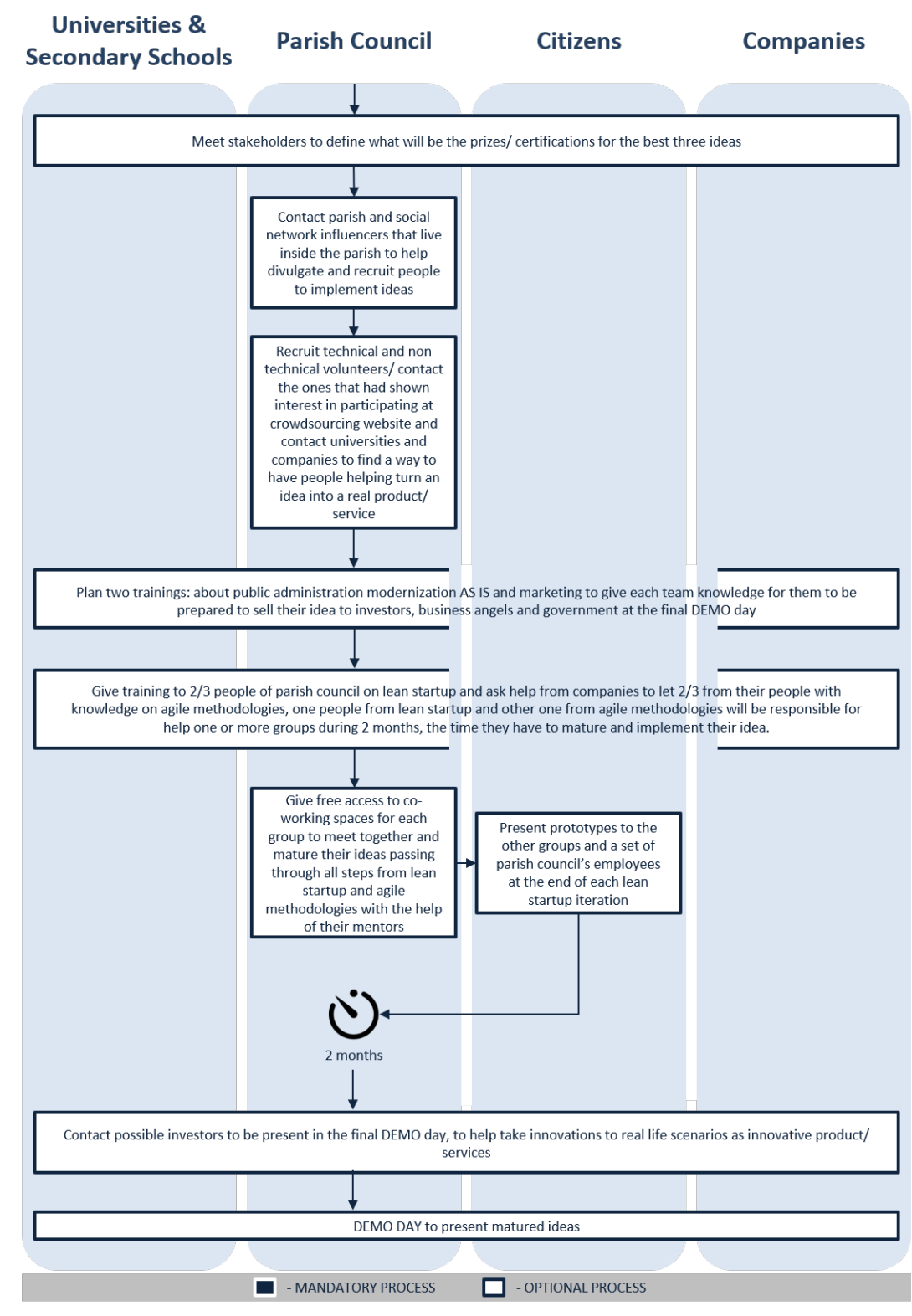

Fig. 6. Framework Implementation Phase 4 
At the end of the first iteration of the innovation accelerator for parishes, when some ideas had already been implemented, it was suggested evaluating the possibility to create a parish delivery center to help implement future ideas and mature the existing ones, as people had already knowledge about the parish council's reality, public administration and innovation methodologies. It is suggested recruiting someone to manage social networks of parish council in order to get closer to citizens, getting their attention on what is being done, as well as influence external opinions with the help of parish influencers.

\section{Discussion}

In this section, three analysis will be made, regarding utility, viability of implementation and improvements based on the answers from validation phase. Then a general evaluation to the proposed framework will be done based on the previous analysis. So, with respect to the proposed conceptual framework and with regard to the utility of it, the three participants of the focus group meeting agreed that the proposed accelerator is very useful. It was considered, by the participants, as indispensable and seen as a way to agglutinate citizens and public administration letting citizens participate more and be more involved, although they express their concerns regarding the need of adapting the process to each parish's reality enforcing the idea that one size does not fits all, it depends on the parish itself and on its stratum. Also, and still regarding the utility of the proposed accelerator it was a shared idea that this could be amazing, specially, as a way to force public service itself to be upgraded and its skills in some subjects. With the adoption of this framework, is was considered that it is important to get parishes closer to what is considered the state of the art. Internal parish improvement is a progress that is already very important, independent on the improvement on citizens participation, as it was considered easier to get citizens involved. The utility of the proposed accelerator was also evaluated in a way that the type of communication channels included in it are fundamental nowadays, so it was a positive point regarding the utility of the accelerator. When talking about observations on what was proposed and an evaluation on how viable it is, things were discussed like the need to get help from city council on communication phases as a premise for frameworks implementation as it was proposed to be one of the starting points of the framework near citizens, the need to have a solid network between city council and parish council and to clarify with citizens what were the competences of city councils and the ones from parish councils as today they do not know yet to whom they should ask things on specific subjects. As a way to get a more sophisticated framework, it was proposed that it is really fundamental to look into public service levels, analyze also the sophistication of the population itself and last but not the least evaluate the levels of participation from citizens. Those three gaps need to be evaluated and improved even before starting frameworks implementation as those will influence the success of it. Although and besides all the previous observations, the framework was considered not as the perfect model for parishes but as a very advanced one 
following the needs of parish councils today, as the one who perfectly fits what is being done at city council's level. Also, as a positive point to the possibility of implementing this framework it has the ability of parish councils to adapt, as they are constantly changing and adapting to new competences that city council delegates on them. Another observation made about the proposed framework was that it was considered mandatory involving people from all ages in it and using different communication channels. By combining this two, it is possible to get mixed and progressive models of dematerialization. To conclude, it was considered viable the proposed framework as it would contribute to define a procedures matrix of citizens relationship. As criticism and suggestions for improvement, all participants agree that it would only be possible to evaluate with a practical application of the proposed framework and tests around it. In general, the proposed framework fulfills the needs of parishes in bringing parishes closer to citizens by letting them have an active voice and also in improving public administration services and skills. So, the process included in this framework is fundamental not only for today's reality of parish councils but also to guide them to the future. It is understood that it has utility, although it needs some adaptations to different parishes realities, a more detailed communication phase where city councils must be an intervenient and the possibility to have a way to evaluate the three gaps of sophistication mentioned above as a way to adapt the framework to each parish reality.

\section{Conclusions and future work}

During this work subjects like public administration (national and international), smart cities and innovation \& creativity were studied as a starting point to be able to design a framework that later on was validated by a focus group meeting by people with knowledge on public administration, especially on local public administration subjects. An improvement to the proposed model was considered as fundamental, after validating the framework, it was concluded that some processes must include as intervenient the city council as it has the resources to help take parishes to the next level. A limitation of this work was the fact that it was not possible to validate this framework by practical application, it was considered that it should be done in the future in order to improve it based on a practical application in a real-life scenario. However focus group was composed by people with knowledge on different parishes in order to enrich the inputs. As last consideration for future work on this subject of smartness inside parish, it is considered important to evaluate the option to improve the proposed framework extending ideas contest and innovation lab to several parishes instead of implementing it in only one parish at a time. However and besides all the future work identified previously, it is important to mention that predefined objectives of this work were achieved. By the application of the proposed framework and according to what was the feedback collected at validation phase, parishes will become smarter by the implementation of the proposed innovation accelerator. 


\section{References}

1. Cardoso, J. : Sistemas de informação para a modernização administrativa. $11 .^{\circ}$ Encontro de Arquivos Municipais. Esposende: BAD - Bibliotecários, arquivistas e documentistas. (2014)

2. Royo, S., \& Yetano, A. : "Crowdsourcing" as a tool for e-participation: two experiences regarding CO2 emissions at municipal level. Electronic Commerce Research, Vol 15, pp. 323-348, ISSN: 1389-5753 (2015)

3. Walters, D. : Smart cities, smart places, smart democracy: Form-based codes, electronic governance and the role of place in making smart cities. Intelligent Buildings International, Vol 3, pp. 198-218, DOI: 10.1080/17508975.2011.586670 (2011)

4. Panagiotopoulos, P., Al-Debei, M., Fitzgerald, G., \& Elliman, T. : A business model perspective for ICTs in public engagement. Government Information Quarterly, Vol 29, pp. 192-202, DOI: 10.1016/j.giq.2011.09.011 (2012)

5. EUROCITIES : Smart city baseline report Lisbon. EUROCITIES , (2017)

6. Governo quer freguesias com mais meios e mais competências, https://www.portugal.gov.pt/pt/gc21/comunicacao/noticia?i=governo-querfreguesias-com-mais-meios-e-mais-competencias. Last accessed 26 Jan 2018

7. Rodrigues, C. : Governação de organizações públicas em Portugal: A emergência de modelos diferenciados. Edições Pedago, LDA, Mangualde (2011)

8. Grimmelikhuijsen, S., \& Meijer, A. : Open data for democracy: Developing a theoretical framework for open data use. Government Information Quarterly, Vol 34, pp. 45-52, DOI: 10.1016/j.giq.2017.01.001 (2017)

9. Silva, C., Lamas, M., Castro, R., Silva, S., \& Rocha, Á. : Governo Electrónico nas Juntas de Freguesia: Situação na Região do Minho, (2018)

10. Almeida Henriques: "Smart cities" precisam de apoios, http://www.jornaldenegocios.pt/negocios-iniciativas/cidades-

inteligentes/detalhe/almeida-henriques-smart-cities-precisam-de-apoios. Last accessed 30 Mar 2017

11. Helbing, D., \& Balietti, S. : How to create an innovation accelerator. The European Physical Journal Special Topics, Vol 195, pp. 101-136, DOI: 10.2139/ssrn.1753796 (2011)

12. Mateus, J. C. : O governo eletrónico, a sua aposta em Portugal e a importância das tecnologias de comunicação para a sua estratégia. Revista de Estudos Politécnicos, Vol VI nº 9 , pp. 23-48, ISSN: 1645-9911 (2008)

13. Nova app faz ligação direta às juntas de freguesias, http://visao.sapo.pt/actualidade/sociedade/2017-10-30-Nova-app-faz-ligacaodireta-as-juntas-de-freguesias. Last accessed 30 Oct 2017

14. Primeiro desafio para "smart cities" é de back-office, https://www.computerworld.com.pt/2017/05/05/primeiro-desafio-para-smartcities-e-de-back-office/. Last accessed 5 May 2012

15. Azevedo, C.: Tecnologias e pessoas mais velhas: Importância do iso e apropriação das novas tecnologias de informação e comunicação para as relações sociais de pessoas mais velhas em Portugal (2013)

16. Ferreira, N. C., Ferreira, F. A., Marques, C. S., Ilander, G. O.-B., \& Çipi, A. : Challenges in the implementation of public electronic services: lessons from a regional-based study. Journal of Business Economics and Management, Vol 16(5), pp. 962-979, ISSN: 1611-1699 (2015)

17. Regime Jurídico das autarquias locais, http://www.pgdlisboa.pt/leis/lei_mostra _articulado.php?nid1̄990\&tabela=leis. Last accessed 12 Sep 2013 
18. Albino, V., Berardi, U., \& Dangelico, R. M.: Smart Cities: Definitions, Dimensions, Performance, and Initiatives. Journal of Urban Technology, Vol $22 \mathrm{n}^{\circ} 1$, pp. 3-21, DOI: $10.1080 / 10630732.2014 .942092$ (2015)

19. The 3 Generations Of Smart Cities, https://www.fastcompany.com/3047795/the3-generations-of-smart-cities. Last accessed 8 Oct 2015

20. INTELI : Smart cities Portugal roadmap In brief. INTELI, (2014)

21. Neto, M. d., Rego, J. S., Neves, F. T., \& Cartaxo, T. M. : Smart \& open cities: Portuguese municipalities open data policies evaluation. 12th Iberian Conference on Information Systems and Technologies (CISTI), DOI: 10.23919/CISTI.2017.7975912 (2017)

22. It's a fast, VUCA world: the trends and forces shaping innovation, https://www.theinovogroup.com/its-a-fast-vuca-world/. Last accessed 1 Sep 2014

23. Six Lessons for Corporations Building Innovation Accelerators, https://www.innosight.com/insight/six-lessons-for-corporations-buildinginnovation-accelerators/. Last accessed 29 Aug 2018

24. Barsh, J., Capozzi, M. M., \& Davidson, J.: Leadership and Innovation. McKinsey Quarterly , pp. 37-47 (2008)

25. 5 mechanisms to promote innovation, http://www.esadeknowledge.com/view/5mechanisms-to-promote-innovation-174880. Last accessed 5 Jan 2018

26. Sources of innovation funding, https://www.business.qld.gov.au/runningbusiness/growing-business/becoming-innovative/funding/sources. Last accessed 8 Aug 2016

27. Top 10 Sources Of Innovation: Why Your Accelerator Barely Makes The List, https://innov8rs.co/news/top-10-sources-of-innovation-why-your-acceleratorbarely-makes-the-list/. Last accessed 2 Sep 2018

28. Business angels, https://www.innovationpolicyplatform.org/content/businessangels. Last accessed 7 Dec 2018

29. Coworking Space vs. Startup Incubator vs. Accelerator: Which is Best?, https://www.rocketspace.com/tech-startups/coworking-space-vs.-startupincubator-vs.-accelerator-which-is-best. Last accessed 4 Apr 2017

30. The Difference Between Design Thinking, Lean Startup, and Agile, https://medium.com/@SteveGlaveski/the-difference-between-design-thinkinglean-startup-and-agile-5cf07b117562. Last accessed 28 Nov 2017

31. Fernandes, S. : Innovation Accelerators As Entrepreneurial And Interdisciplinary Engines: The Portuguese Case. Journal of Spatial and Organizational Dynamics, pp. 213-228, ISSN: 1647-3183 (2016)

32. Jennifer Auer, C., \& D'Ippolito, M. : Innovation Accelerators: Defining Characteristics among startup assistance organizations . College Park, Maryland: Small Business Administration - Office of Advocacy., DOI: 10.13140/RG.2.2.36244.09602 (2014)

33. How to design your own innovation accelerator: a checklist. Obtido de Board of innovation, https://www.boardofinnovation.com/blog/2015/10/01/a-checklistfor-designing-your-own-innovation-accelerator/. Last accessed 1 Oct 2015

34. Baskerville, R. L., Kaul, M., \& Storey, V. C.: Genres of Inquiry in Design-Science Research: Justification and Evaluation of Knowledge Production. McKinsey Quarterly, Vol 39 nº 3, pp. A1-A9 (2015) 